\title{
Cold-seep ostracods from the western Svalbard margin: direct palaeo-indicator for methane seepage?
}

\author{
Moriaki Yasuhara ${ }^{1}$, Kamila Sztybor ${ }^{2}$, Tine L. Rasmussen ${ }^{2}$, Hisayo Okahashi ${ }^{1}$, Runa Sato ${ }^{1,3}$, and \\ Hayato Tanaka ${ }^{4}$ \\ ${ }^{1}$ School of Biological Sciences and Swire Institute of Marine Science, The University of Hong Kong, \\ Kadoorie Biological Sciences Building, Pokfulam Road, Hong Kong SAR, China \\ ${ }^{2} \mathrm{CAGE}$ - Centre for Arctic Gas Hydrate, Environment and Climate, Department of Geology, \\ UiT The Arctic University of Norway, Dramsveien 201, 9037 Troms $\varnothing$, Norway \\ ${ }^{3}$ Department of Marine Biosciences, Tokyo University of Marine Science and Technology, 4-5-7 Konan, \\ Minato-ku, Tokyo 108-8477, Japan \\ ${ }^{4}$ Research Center for Marine Education, Ocean Alliance, The University of Tokyo, Hongo 7-3-1, Bunkyo-ku, \\ Tokyo 113-0033, Japan
}

Correspondence: Moriaki Yasuhara (moriakiyasuhara@gmail.com)

Received: 24 June 2017 - Revised: 27 August 2017 - Accepted: 19 September 2017 - Published: 5 January 2018

\begin{abstract}
Despite their high abundance and diversity, microfossil taxa adapted to a particular chemosynthetic environment have rarely been studied and are therefore poorly known. Here we report on an ostracod species, Rosaliella svalbardensis gen. et sp. nov., from a cold methane seep site at the western Svalbard margin, Fram Strait. The new species shows a distinct morphology, different from other eucytherurine ostracod genera. It has a marked similarity to Xylocythere, an ostracod genus known from chemosynthetic environments of wood falls and hydrothermal vents. Rosaliella svalbardensis is probably an endemic species or genus linked to methane seeps. We speculate that the surface ornamentation of pore clusters, secondary reticulation, and pit clusters may be related to ectosymbiosis with chemoautotrophic bacteria. This new discovery of specialized microfossil taxa is important because they can be used as an indicator species for past and present seep environments (http: //zoobank.org/urn:lsid:zoobank.org:pub:6075FF30-29D5-4DAB-9141-AE722CD3A69B).
\end{abstract}

\section{Introduction}

It is important to understand causes behind changes in the activity of release of methane in the geological past because methane is a $\sim 25$ times more powerful greenhouse gas than carbon dioxide, and it constitutes an important factor in regional and global climate change (Nisbet and Chappellaz, 2009; Consolaro et al., 2015; Hopcroft et al., 2017). Reconstructions of deep-sea seep activities in the geological past have often been based on $\delta^{13} \mathrm{C}$ values measured in foraminiferal shells, but the signals are often caused by secondary mineralization of diagenetic carbonate, making inferences about timing of seepage events difficult (Uchida et al., 2008; Consolaro et al., 2015; Sztybor and Rasmussen, 2017a). So far, apart from certain macrofossils (e.g. vesicomyid bivalves), very few other indicator species for the de- tection of past methane seepage in sedimentary records have been described (e.g. Sen Gupta et al., 1997; Bernhard et al., 2001). Because of their large size and low abundance compared to microfossils, quantitative studies of deep-sea macrofaunas are difficult.

Methane hydrate provinces are widely distributed in the Arctic Ocean (Biastoch et al., 2011). The stability of methane hydrate is known to be sensitive to climate change (Berndt et al., 2014). In turn, methane seepage may have contributed to rapid climate change (Nisbet and Chappellaz, 2009; Dickens, 2011). Release of methane creates a unique chemosynthetic ecosystem (Van Dover et al., 2003), and thus there may be unique microfossil communities or endemic microfossil species providing unequivocal indications for palaeomethane seepage. 

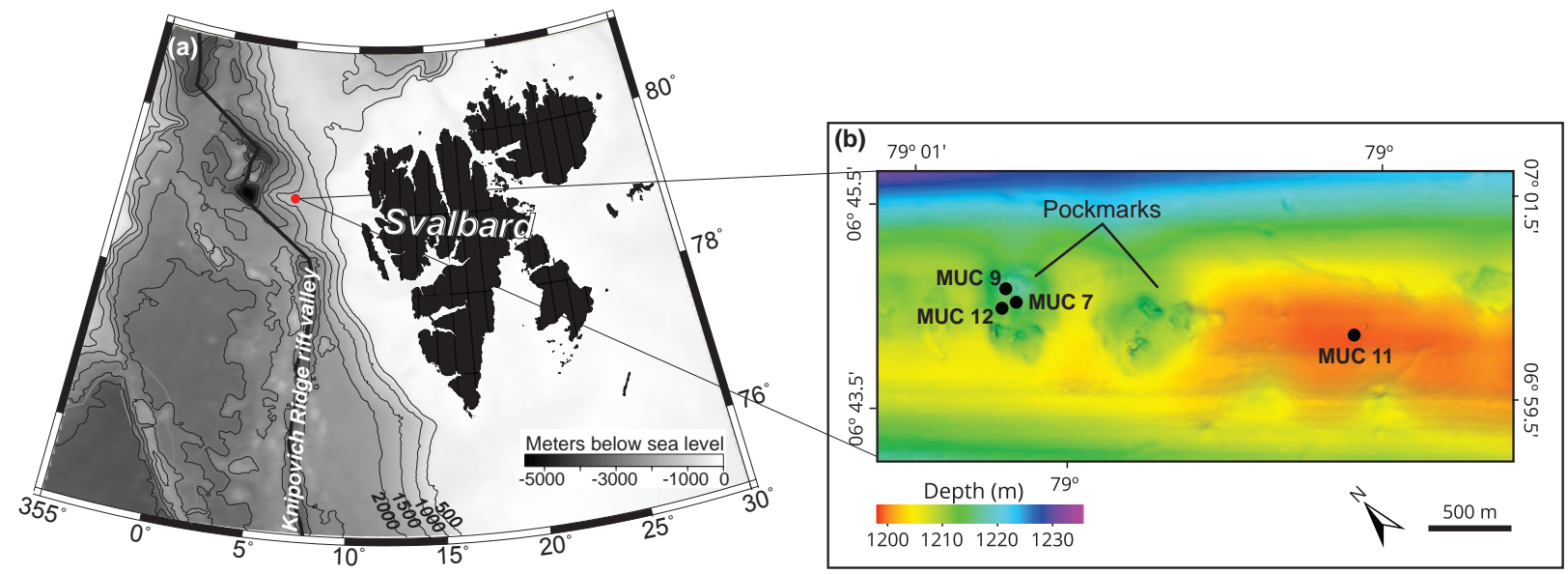

Figure 1. Locality maps. (a) Map of Svalbard and the research area marked by red dot. (b) Details of research area showing positions of the multicore stations. Pockmark bathymetry data are from Bünz et al. (2012).

Ostracoda are small crustaceans that have bivalve-like calcified shells. They are diverse: $>20000$ living species are estimated, and, among them, $\sim 8000$ species have been described (Horne et al., 2002; Rodriguez-Lazaro and RuizMuñoz, 2012). Most species are sensitive to changes in various environmental factors (e.g. temperature, salinity, oxygen, organic matter supply) (Horne et al., 2002; Schellenberg, 2007; Yasuhara and Cronin, 2008; Mesquita-Joanes et al., 2012). Their calcified shells are abundantly preserved in marine sediments (Yasuhara et al., 2017). Thus, ostracods are a widely used microfossil group in the reconstruction of various palaeoceanographic and palaeoclimatological changes. They have been successfully applied in the reconstruction of past sea-level, temperature, salinity, and other environmental changes (Frenzel and Boomer, 2005; Yasuhara and Seto, 2006; Iwatani et al., 2012; Cronin, 2015). However, methane seep ostracods remain poorly investigated, and any ostracod species, genera, or faunas endemic or specific in methane seep environments have not been known until now (Karanovic and Brandão, 2015).

Here we report on deep-sea ostracods from Vestnesa Ridge in the eastern Fram Strait, carefully collected from an active pockmark generated by strong and persistent release of methane from the seafloor (e.g. Bünz et al., 2012; Sztybor and Rasmussen, 2017a, b). We discovered Rosaliella svalbardensis gen. et sp. nov., and this species or genus is likely endemic to methane seepage environments; thus, their well-calcified microfossil shells can be useful indicators of methane release in the past and present.

\section{Materials and methods}

The samples were collected with a video-guided multicorer (MUC) during the RV Poseidon cruise 419 to Vestnesa Ridge in August 2011 (Fig. 1). In total three sites within the cold- seep pockmark (MUC 7, 9, 12) and one control station outside the pockmark (MUC 11) were sampled (Fig. 1; Table 1). The cores of MUC 7 and MUC 12 were taken in bacterial mats, while MUC 9 was retrieved from a field of (chemosynthetic) tubeworms. Each of the cores was subsampled on board. The cores were cut into $1 \mathrm{~cm}$ thick slices, preserved in alcohol stained with rose bengal, and kept cool until further processing. For this study, the core top $1 \mathrm{~cm}$ slices were used. In the laboratory the samples were wet-sieved $(0.063,0.1$, and $1 \mathrm{~mm}$ ) and then dried. We used the $>100 \mu \mathrm{m}$ size fraction for ostracod analysis. This sieve size allows one to obtain adult and late-stage juvenile specimens of most species. All ostracod specimens in a sample were picked, mounted on microfossil slide, and identified to species level. The number of specimens refers to valves.

Uncoated ostracod specimens were digitally imaged with a Hitachi S-3400N variable pressure scanning electron microscope (SEM) in low-vacuum mode, at the Electron Microscope Unit, The University of Hong Kong. Figured specimens are deposited in the National Museum of Natural History (Washington, DC, USA; catalogue numbers USNM 696651-696672). M. Yasuhara's personal catalog number (Seep1-15, 17-23) is indicated in parentheses. For the higher classification scheme, we mainly refer to the World Ostracoda Database (Brandão et al., 2017), Whatley et al. (1993), and Horne et al. (2002).

\section{Abbreviations}

$\mathrm{LV}$, left valve; $\mathrm{RV}$, right valve; $\mathrm{L}$, length; $\mathrm{H}$, height.

\section{Systematic palaeontology}

Subclass Podocopa Sars, 1866

Order Podocopida Sars, 1866 
Table 1. Sample and locality information.

\begin{tabular}{lllrrrl}
\hline Site & Sample & Date & Latitude (N) & Longitude (E) & Depth $(\mathrm{m})$ & Note \\
\hline POS419-675 & MUC9 & $28 / 8 / 2011$ & $79^{\circ} 00.466^{\prime}$ & $06^{\circ} 54.279^{\prime}$ & 1241 & Siboglinidae field \\
POS419-676 & MUC11 & $28 / 8 / 2011$ & $78^{\circ} 59.774^{\prime}$ & $06^{\circ} 58.064^{\prime}$ & 1191 & Control site \\
POS419-678 & MUC12 & $29 / 8 / 2011$ & $79^{\circ} 00.417^{\prime}$ & $06^{\circ} 54.131^{\prime}$ & 1235 & Bacterial mat, strongly bubbling \\
POS419-658 & MUC7 & $24 / 8 / 2011$ & $79^{\circ} 00.415^{\prime}$ & $06^{\circ} 54.229^{\prime}$ & 1204 & Beggiatoa mat \\
\hline
\end{tabular}

Suborder Cytherocopina Baird, 1850

Superfamily Cytheroidea Baird, 1850

Family Cytheruridae Müller, 1894

Genus Rosaliella gen. nov.

Derivation of name. In honour of Rosalie F. Maddocks (University of Houston, USA) for her work on ostracods from chemosynthetic environments.

Type species. Rosaliella svalbardensis gen. et sp. nov.

Diagnosis. A large, oval-shaped Cytheruridae genus with primary reticulation and pore clusters (i.e. secondary reticulation). No ventrolateral or dorsolateral ridge on valve surface. Caudal process lacking. Hingement peratodont type (Bate, 1972). Subcentral muscle scars composed of one boomerang-shaped frontal scar and a vertical row of four elongate adductor scars.

Remarks. Rosaliella gen. nov. is most similar to species of Xylocythere. Both Xylocythere and Rosaliella have welldeveloped primary reticulation and pore clusters and similar subcentral muscle scars and hingement (e.g. see Maddocks and Steineck, 1987; Steineck et al., 1990, for Xylocythere). Especially the type species of both genera (i.e. Rosaliella svalbardensis gen. et sp. nov. and Xylocythere turnerae Maddocks and Steineck, 1987) have substantial similarity, for example, in the general patterns of primary reticulation and pore conuli distribution. However, Xylocythere species have a ventrolateral ridge and a spine on their posterior end, a more rectangular outline, and a less inflated shell (Maddocks and Steineck, 1987; Steineck et al., 1990). In contrast, Rosaliella does not have any ridge or spine, and has an oval outline and more inflated shell. In internal view, Xylocythere species have enlarged (tooth-like) anterior and posterior ends of median hinge bar in LV (Maddocks and Steineck, 1987; Steineck et al., 1990), but Rosaliella lacks such a tooth-like structure at each end of the median hinge bar in LV. Because these differences are substantial, we erect Rosaliella gen. nov. as an independent genus from Xylocythere. The type species Rosaliella svalbardensis is also similar to Laocoonella commensalis (de Vos, 1953) in surface ornamentation (de Vos, 1953; de Vos and Stock, 1956). But Rosaliella svalbardensis is much larger than Laocoonella commensalis. In addition, hingement of Lao- coonella is more similar to that of Xylocythere (in lacking denticulation at least in an end of median hinge bar; see de Vos, 1953; Maddocks and Steineck, 1987), rather than that of Rosaliella. Thus, we consider that they are not conspecific or congeneric. Rosaliella is distinct from species of other eucytherurine genera. For example, Rosaliella is different from Cytheropteron by lacking ala and caudal process, although both genera have very similar hingement and subcentral muscle scars and some deep-sea Cytheropteron species lack ala (e.g. see Yasuhara et al., 2009, Yasuhara and Okahashi, 2015, for Cytheropteron). Some species of Eucytherura (e.g. Eucytherura pacifica Ayress, Whatley, Downing and Millson, 1995) have well-developed primary reticulation and pore clusters and very weakly developed caudal process similar to Rosaliella (Ayress et al., 1995; Yasuhara et al., 2009). However, Rosaliella differs from Eucytherura by lacking ridge, spine, and tubercle, and by having arched hingement (hingement is straight or sinuous in Eucytherura) and a comparatively less calcified shell (e.g. see Ayress et al., 1995; Yasuhara et al., 2009, for Eucytherura).

Rosaliella svalbardensis gen. et sp. nov.

(Figs. 2-3)

Derivation of name. From the type locality, Svalbard.

Holotype. Adult female RV, USNM 696652 (Seep2) (Fig. 2f-j).

Paratypes. Adult female LV, USNM 696651 (Seep1) (Fig. 2a-e); adult female LV, USNM 696653 (Seep20) (Fig. 2k-n); adult female RV, USNM 696654 (Seep21) (Fig. 2o-q); adult male LV, USNM 696655 (Seep3) (Fig. 3ad); adult male RV, USNM 696656 (Seep4) (Fig. 3e-i); A-1 juvenile LV, USNM 696657 (Seep5) (Fig. 3j); A-1 juvenile RV, USNM 696658 (Seep6) (Fig. 3k); A-2 juvenile LV, USNM 696659 (Seep7) (Fig. 31); A-2 juvenile RV, USNM 696660 (Seep8) (Fig. 3m).

Type locality and horizon. POS419-678, MUC 12B, 0-1 cm depth; Vestnesa Ridge, western Svalbard margin, Fram Strait, Arctic Ocean; $79^{\circ} 00.417^{\prime} \mathrm{N}, 06^{\circ} 54.131^{\prime} \mathrm{E}$; $1235 \mathrm{~m}$ water depth (Table 1). 

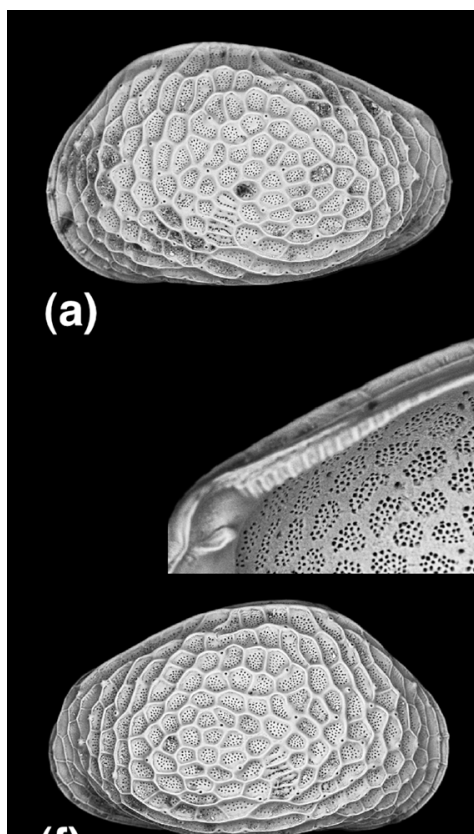

(f)

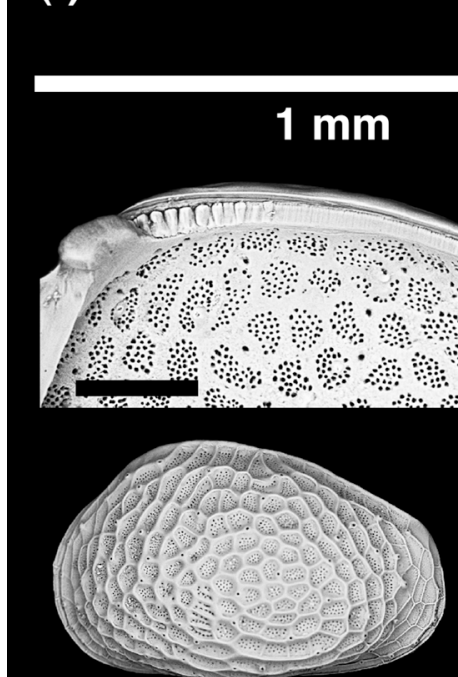

(I)

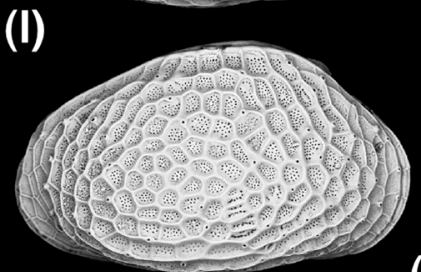

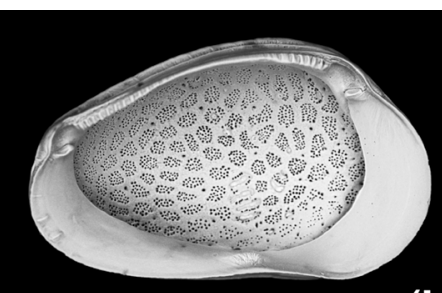

(b)

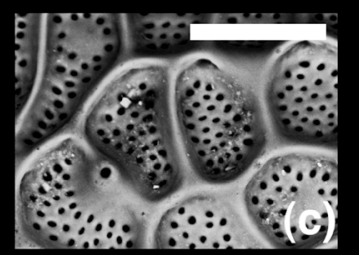

(d)
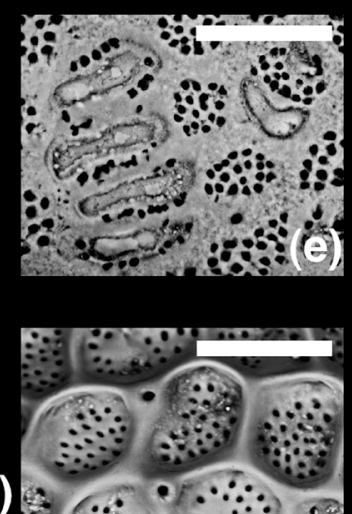

(g) $\because \because \because \because \because \because \because)^{2}$

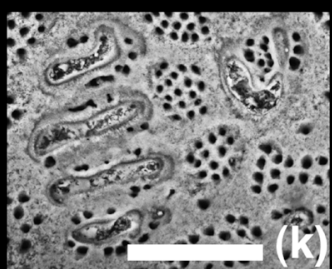

\section{(i)}

(o)
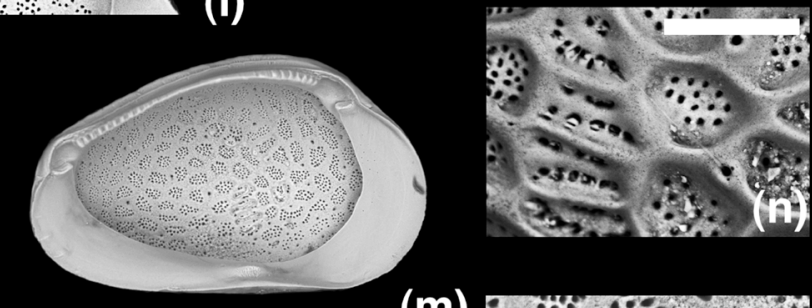

(m)

(p)

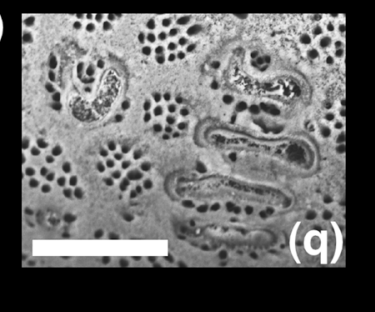

Figure 2. Scanning electron microscopy images of Rosaliella svalbardensis gen. et sp. nov. (a-e) USNM 696651 (Seep1), paratype, adult, female, LV, POS419-678, MUC 12B, 0-1 cm depth. (f-j) USNM 696652 (Seep2), holotype, adult, female, RV, POS419-678, MUC 12B, 0$1 \mathrm{~cm}$ depth. (k-n) USNM 696653 (Seep20), paratype, adult, female, LV, POS419-658, MUC 7, 0-1 cm depth. (o-q) USNM 696654 (Seep21), paratype, adult, female, RV, POS419-658, MUC 7, 0-1 cm depth. (a, c, f, h, l, n, o) Lateral views. (b, d, e, g, i, j, k, k, p, q) Internal views. Scale bars: $1 \mathrm{~mm}$ for $(\mathbf{a}, \mathbf{b}, \mathbf{f}, \mathbf{g}, \mathbf{l}, \mathbf{m}, \mathbf{o}, \mathbf{p}) ; 100 \mu \mathrm{m}$ for $(\mathbf{d}, \mathbf{i}) ; 50 \mu \mathrm{m}$ for $(\mathbf{c}, \mathbf{e}, \mathbf{h}, \mathbf{j}, \mathbf{k}, \mathbf{n}, \mathbf{q}) .1 \mathrm{~mm}$ scale bar in the middle part of the figure. Other scale bars in each panel. 


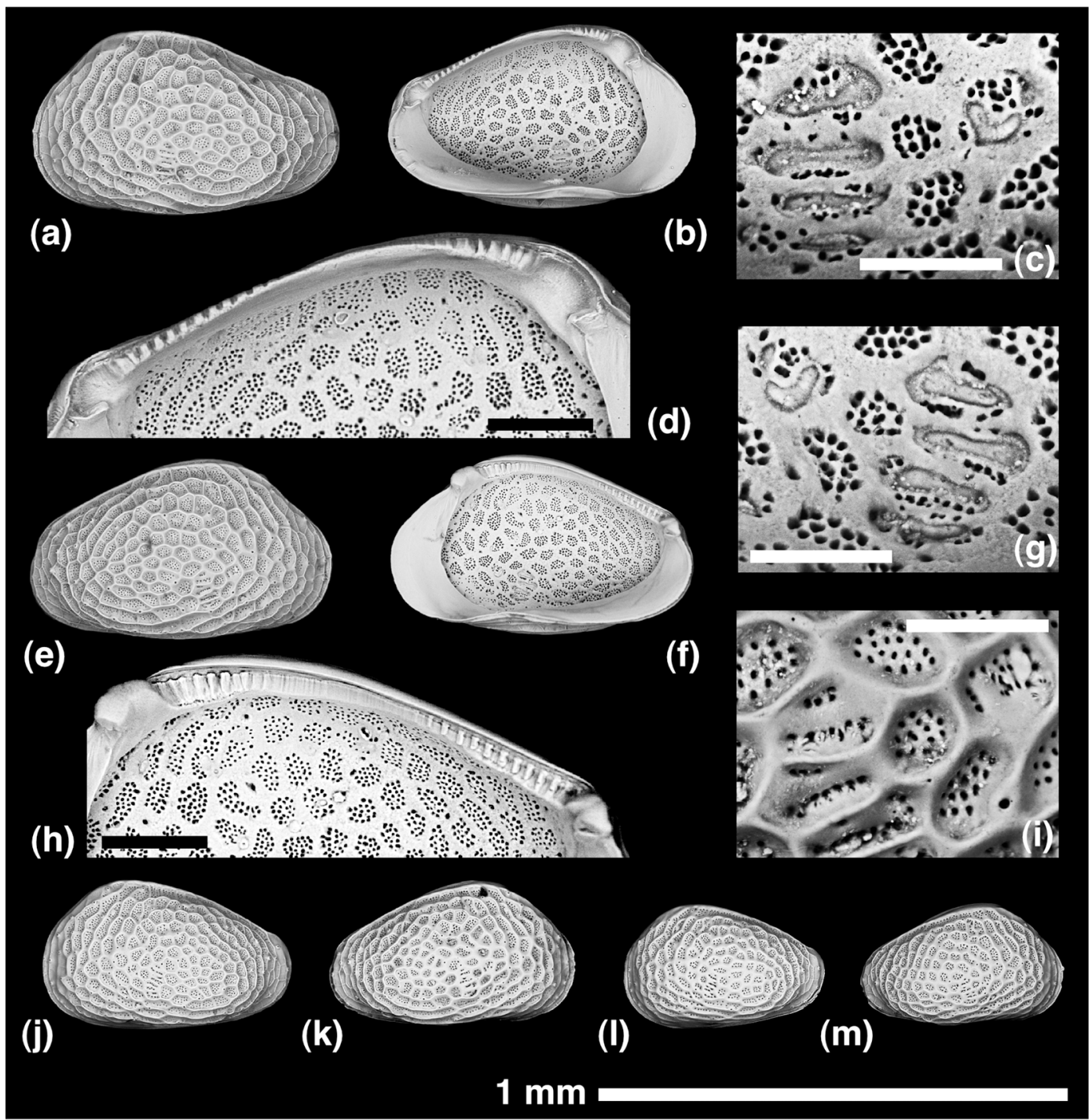

Figure 3. Scanning electron microscopy images of Rosaliella svalbardensis gen. et sp. nov. (a-d) USNM 696655 (Seep3), paratype, adult, male, LV, POS419-678, MUC 12B, 0-1 cm depth. (e-i) USNM 696656 (Seep4), paratype, adult, male, RV, POS419-678, MUC 12B, 0-1 cm depth. (j) USNM 696657 (Seep5), paratype, A-1 juvenile, LV, POS419-678, MUC 12B, 0-1 cm depth. (k) USNM 696658 (Seep6), paratype, A-1 juvenile, RV, POS419-678, MUC12B, 0-1 cm depth. (l) USNM 696659 (Seep7), paratype, A-2 juvenile, LV, POS419-678, MUC 12B, 0-1 cm depth. (m) USNM 696660 (Seep8), paratype, A-2 juvenile, RV, POS419-678, MUC 12B, 0-1 cm depth. (a, e, i, j, k, l, m) Lateral views. (b, c, d, f, $\mathbf{g}, \mathbf{h})$ Internal views. Scale bars: $1 \mathrm{~mm}$ for $(\mathbf{a}, \mathbf{b}, \mathbf{e}, \mathbf{f}, \mathbf{j}, \mathbf{k}, \mathbf{l}, \mathbf{m}) ; 100 \mu \mathrm{m}$ for $(\mathbf{d}, \mathbf{h}) ; 50 \mu \mathrm{m}$ for $(\mathbf{c}, \mathbf{g}, \mathbf{i}) .1 \mathrm{~mm}$ scale bar on the bottom right of the figure. Other scale bars in each panel.

Dimensions. USNM 696652 (Seep2) (holotype), $\mathrm{L}=672 \mu \mathrm{m}, \quad \mathrm{H}=404 \mu \mathrm{m} ; \quad$ USNM $696651 \quad$ (Seep1) (paratype), $\mathrm{L}=680 \mu \mathrm{m}, \mathrm{H}=411 \mu \mathrm{m} ; \quad \mathrm{USNM} 696655$ (Seep3) (paratype), $\mathrm{L}=656 \mu \mathrm{m}, \mathrm{H}=395 \mu \mathrm{m} ; \quad \mathrm{USNM}$ 696656 (Seep4) (paratype), $\mathrm{L}=642 \mu \mathrm{m}, \mathrm{H}=382 \mu \mathrm{m}$.

Diagnosis. A species of Rosaliella ornamented with well-developed primary and secondary reticulation.

Description. Carapace well calcified, medium in size, highest at anterior third of length. Outline oval in lateral view; anterior margin evenly rounded in ventral half and straight in dorsal half; posterior margin rounded; dorsal and ventral margins rounded. Anterodorsal corner rounded; posterodorsal corner weakly angular. Lateral surface ornamented with well-developed, regular primary reticulation and pore clusters (i.e. secondary reticulation), and lacking any spines or ridges; normal pores situated on muri. Inner lamella broad. Hingement peratodont type; anterior and posterior terminal teeth in RV smooth; median hinge element in $\mathrm{RV}$ denticulate especially in posterior and anterior thirds; median hinge bar in LV denticulate in posterior and anterior 


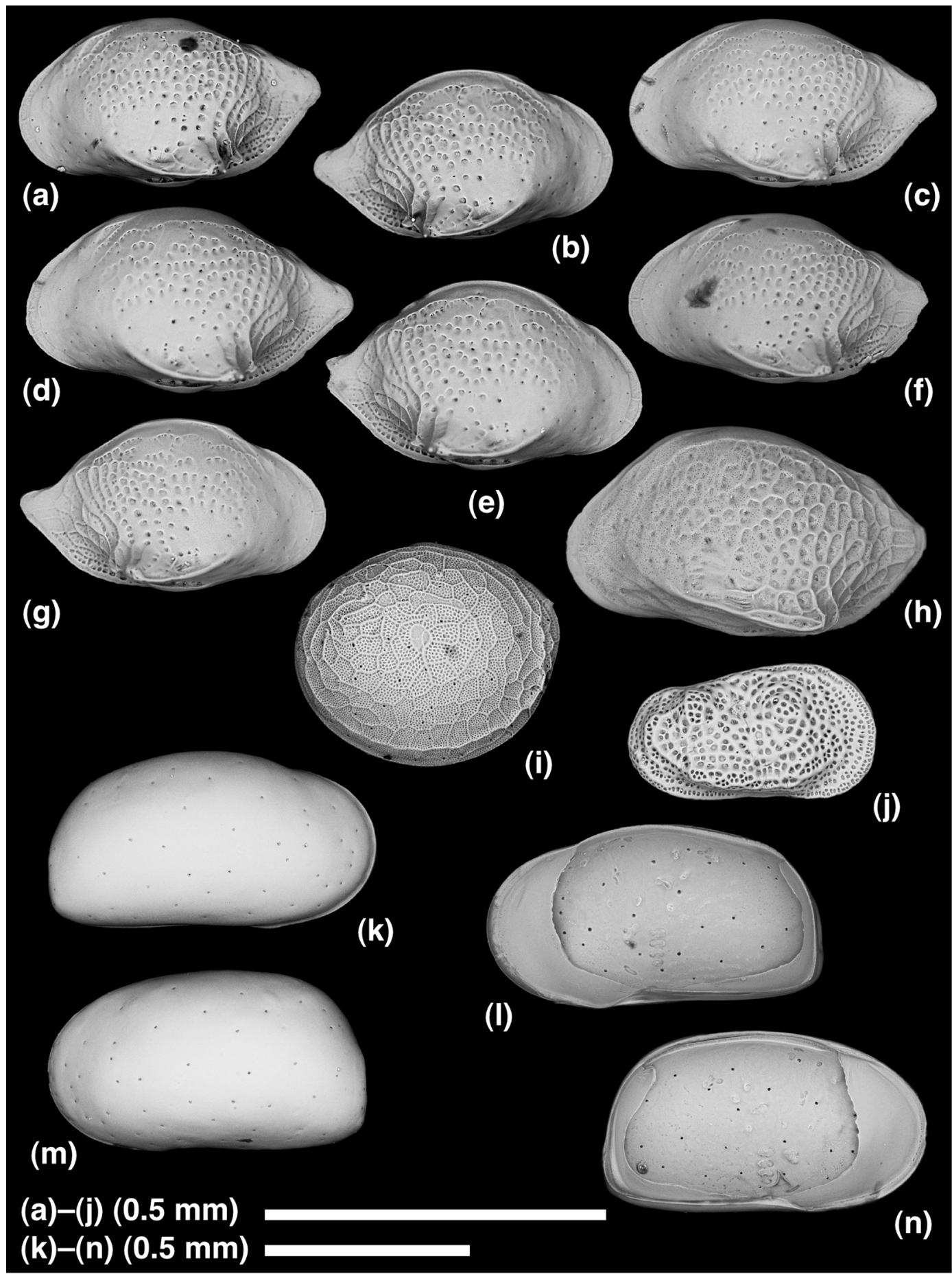

Figure 4. Scanning electron microscopy images of Cytheropteron carolinae, Cytheropteron cf. pseudoinflatum, Polycope bireticulata, Cluthia cluthae, and Krithe glacialis. (a-g) Cytheropteron carolinae Whatley and Coles, 1987. (a) USNM 696661 (Seep9), adult, LV, POS419-678, MUC 12B, 0-1 cm depth. (b) USNM 696662 (Seep10), adult, RV, POS419-678, MUC 12B, 0-1 cm depth. (c) USNM 696663 (Seep17), adult, LV, POS419-675, MUC 9, 0-1 cm depth. (d) USNM 696664 (Seep11), adult, LV, POS419-678, MUC 12B, 0-1 cm depth. (e) USNM 696665 (Seep12), adult, RV, POS419-678, MUC 12B, 0-1 cm depth. (f) USNM 696666 (Seep22), adult, LV, POS419-658, MUC 7, 0-1 cm depth. (g) USNM 696667 (Seep23), adult, RV, POS419-658, MUC 7, 0-1 cm depth. (h) Cytheropteron cf. pseudoinflatum Whatley and Eynon 1996, USNM 696668 (Seep18), adult, LV, POS419-675, MUC 9, 0-1 cm depth. (i) Polycope bireticulata Joy and Clark, 1977, USNM 696669 (Seep13), RV, POS419-678, MUC 12B, 0-1 cm depth. (j) Cluthia cluthae (Brady, Crosskey, and Robertson, 1874), USNM 696670 (Seep14), adult, RV, POS419-678, MUC 12A, 0-1 cm depth. (k-n) Krithe glacialis Brady, Crosskey, and Robertson, 1874. (k-l) USNM 696671 (Seep15), adult, female, RV, POS419-675, MUC 9, 0-1 cm depth. (m-n) USNM 696672 (Seep19), adult, female, LV, POS419-675, MUC 9, 0-1 cm depth. (a-k, m) Lateral views. (l, n) Internal views. $0.5 \mathrm{~mm}$ scale bars on the bottom left of the figure. 
Table 2. Ostracod data summary.

\begin{tabular}{|c|c|c|c|c|c|}
\hline Site & POS419-658 & POS419-675 & POS419-676 & POS419-678 & POS419-678 \\
\hline Sample & MUC 7 & MUC 9 & MUC 11 & MUC 12A & MUC 12B \\
\hline Note* & Seep w Ba & Seep w T & Control & Seep w Ba, Bu & Seep w $\mathrm{Ba}, \mathrm{Bu}$ \\
\hline Core depth & $0-1 \mathrm{~cm}$ & $0-1 \mathrm{~cm}$ & $0-1 \mathrm{~cm}$ & $0-1 \mathrm{~cm}$ & $0-1 \mathrm{~cm}$ \\
\hline Argilloecia cf. robinwhatleyi & & 2 & & & \\
\hline Argilloecia sp. 1 of Yasuhara et al. (2014b) & & 6 & & & \\
\hline Australoecia posteroacuta & & 2 & & & \\
\hline Cluthia cluthae & & 2 & & 1 & \\
\hline Cytheropteron carolinae & 2 & 8 & & & 9 \\
\hline Cytheropteron higashikawai & & & 1 & & 1 \\
\hline Cytheropteron inflatum & & & 1 & & \\
\hline Cytheropteron perlaria & & 1 & & & \\
\hline Cytheropteron cf. pseudoinflatum & & 1 & & & \\
\hline Krithe glacialis & & 24 & 1 & & \\
\hline Muellerina abyssicola & & 2 & & & \\
\hline Paracytherois chukchiensis & & 6 & & & \\
\hline Polycope bireticulata & & 2 & & & 2 \\
\hline Pseudocythere caudata & & 11 & & & \\
\hline Rosaliella svalbardensis gen. et sp. nov. & 2 & & & 4 & 22 \\
\hline Swainocythere cf. chejudoensis & & & & & 2 \\
\hline Thaerocythere crenulata & & 1 & & & \\
\hline Total & 4 & 68 & 3 & 5 & 36 \\
\hline
\end{tabular}

thirds, and smooth in middle part. Frontal scar boomerangshaped; adductor muscle scars consisting of vertical row of four elongate scars.

Remarks. Rosaliella svalbardensis gen. et $\mathrm{sp}$. nov. is most similar to Xylocythere turnerae Maddocks and Steineck, 1987 (see the remarks section of the genus above), but distinguished by having an oval outline and lacking a ventrolateral ridge.

Distribution. This species is known only from the methane seepage locality of Vestnesa Ridge, western Svalbard margin.

\section{Results and discussion}

\subsection{Rosaliella svalbardensis as palaeo-methane seep indicator}

Rosaliella svalbardensis shows clear similarity to Xylocythere species that are known from other chemosynthetic (i.e. wood fall and hydrothermal vent) environments (Maddocks and Steineck, 1987; Steineck et al., 1990; Van Harten, 1993; Maddocks, 2005). They are rarely found in normal soft sediments (Corrége, 1993; Karanovic and Brandão, 2015; Yasuhara et al., 2009). In these normal soft sediments, the Xylocythere specimens may have been transported from nearby chemosynthetic environments. Within a pockmark,
Rosaliella svalbardensis occurs in seepage sites with bacterial mats (MUC 7, 12), but it is absent in the tubeworm field (MUC 9) and in the nearby control site, $500 \mathrm{~m}$ from the pockmark (MUC 11) (Tables 1-2). Notably, this species shows high abundance in a site with strong bubbling of methane (MUC 12; Tables 1-2). In addition, although deep-sea ostracods from normal soft sediments are well studied in the North Atlantic, Nordic seas, and Arctic Ocean (i.e. adjacent regions to the study sites) (Whatley and Coles, 1987; Whatley et al., 1996, 1998; Didié and Bauch, 2000; Yasuhara et al., 2009, 2014a, b; Alvarez Zarikian, 2009; Yasuhara and Okahashi, 2014, 2015; Gemery et al., 2017), any similar species or genus to Rosaliella svalbardensis has not been reported.

Van Harten (1993) suggested that pore clusters in Xylocythere is related to ectosymbiosis of chemoautotrophic bacteria (also see Maddocks, 2005). We observed the same structure in Rosaliella (Figs. 2-3). Furthermore, Keysercythere recently discovered from a wood fall environment has the pore clusters even though this genus is distant from Xylocythere or Rosaliella phylogenetically, belonging to different families (Karanovic and Brandão, 2015). Thus, the pore clusters observed in these genera may be convergence and evolutionary adaptation to chemosynthetic environments.

These results indicate that Rosaliella svalbardensis is associated with methane seepage and probably endemic to the methane seep environment. More specifically, the habitat of this species is probably related to the presence of bacte- 
rial mats. Its high abundance in an active seep site suggests that this species can be a good indicator of not only presence/absence but also of the strength of release of methane. Furthermore, Rosaliella svalbardensis has relatively large and well-calcified valves and a distinct morphology (Figs. 23 ). Thus, this species can be used as a direct palaeo-indicator for methane seepage allowing reconstructions of long-term changes in seepage activity. It is likely that fossil valves of this species will be discovered from long sediment cores from methane seep sites.

\subsection{Ostracod fauna in methane seep}

The site from the pockmark within a tubeworm field (MUC 9) shows the highest abundance of ostracods (Table 2; Fig. 4). Almost all species from this site are also known from normal deep-sea soft sediments (Yasuhara et al., 2009, 2014a, b, 2015). A notable point is the relatively high abundance of species with secondary reticulation or pit clusters, i.e. Cytheropteron carolinae Whatley and Coles, 1987, Cluthia cluthae (Brady, Crosskey, and Robertson, 1874), Polycope bireticulata Joy and Clark, 1977 (Fig. 4). They also occur in other cold-seep sites and are absent in the control site (Table 2). Thus, we may suggest that these secondary reticulation and pit clusters are related to ectosymbiosis of chemoautotrophic bacteria, like the pore clusters in Xylocythere (Van Harten, 1993; Maddocks, 2005). However, as noted above, these species are also known from normal deep-sea soft sediments (Freiwald and Mostafawi, 1998; Yasuhara et al., 2009, 2014b; Gemery et al., 2017). This hypothesis remains speculative and further research is needed.

\section{Conclusions}

1. Rosaliella svalbardensis gen. et sp. nov. is described. This species can be a useful indicator of palaeo-methane release.

2. The hypothesis that pore clusters, secondary reticulation, and pit clusters are related to ectosymbiosis of chemoautotrophic bacteria merits further investigation.

3. Macroevolution of chemosynthetic taxa in seep, vent, and organic fall habitats remains poorly understood (Smith et al., 2015). Thus, discovery of specialized taxa for the chemosynthetic environments is important especially in microfossil taxa that have abundant and excellent fossil records in deep-sea sediments and that are widely used in palaeoceanographic research.

Data availability. All data are included in this paper itself.

Competing interests. The authors declare that they have no conflict of interest.
Acknowledgements. We thank Olaf Pfannkuche, Tina Treude, and the crew of the PO-419 cruise for the samples; Sunil Vadakkepuliambatta for the figure with bathymetry of the pockmark area; and Laura Wong and Maria Lo for continuous support. The work described in this article was partially supported by grants from the Research Grants Council of the Hong Kong Special Administrative Region, China (project codes: HKU 17306014, HKU 17311316) (to Moriaki Yasuhara).

Edited by: Thomas M. Cronin

Reviewed by: Anna Stepanova and Ian Boomer

\section{References}

Alvarez Zarikian, C. A.: Data report: late Quaternary ostracodes at IODP Site U1314 (North Atlantic Ocean), Proceedings of the Integrated Ocean Drilling Program, 303/306, 1-22, 2009.

Ayress, M. A., Whatley, R. C., Downing, S. E., and Millson, K. J.: Cainozoic and recent deep sea Cytherurid Ostracoda from the south western Pacific and eastern Indian Oceans, part I: Cytherurinae, Records of the Australian Museum, 47, 203-223, 1995.

Baird, W.: The Natural History of the British Entomostraca, Ray Society, London, 364 pp., 1850.

Bate, R. H.: Upper Cretaceous Ostracoda from the Carnarvon Basin, Western Australia, Special Papers in Palaeontology, 10, 1-85, 1972.

Berndt, C., Feseker, T., Treude, T., Krastel, S., Liebetrau, V., Niemann, H., Bertics, V. J., Dumke, I., Dunnbier, K., Ferre, B., Graves, C., Gross, F., Hissmann, K., Huhnerbach, V., Krause, S., Lieser, K., Schauer, J., and Steinle, L.: Temporal constraints on hydrate-controlled methane seepage off Svalbard, Science, 343, 284-287, 2014.

Bernhard, J. M., Buck, K. R., and Barry, J. P.: Monterey Bay coldseep biota: assemblages, abundance, and ultrastructure of living foraminifera, Deep-Sea Res. Pt. I, 48, 2233-2249, 2001.

Biastoch, A., Treude, T., Rupke, L. H., Riebesell, U., Roth, C., Burwicz, E. B., Park, W., Latif, M., Boning, C. W., Madec, G., and Wallmann, K.: Rising Arctic Ocean temperatures cause gas hydrate destabilization and ocean acidification, Geophys. Res. Lett., 38, L08602, https://doi.org/10.1029/2011GL047222, 2011.

Brady, G. S., Crosskey, H. W., and Robertson, D.: A monograph of the post-Tertiary Entomostraca of Scotland including species from England and Ireland, Annual Volumes (Monographs) of the Palaeontographical Society, London, 28, 1-232, 1874.

Brandão, S. N., Angel, M. V., Karanovic, I., Perrier, V., and Yasuhara, M.: World ostracod database, available at: http://www. marinespecies.org/ostracoda, last access: 22 February 2017.

Bünz, S., Polyanov, S., Vadakkepuliyambatta, S., Consolaro, C., and Mienert, J.: Active gas venting through hydrate-bearing sediments on the Vestnesa Ridge, offshore W-Svalbard, Mar. Geol., 332-334, 189-197, 2012.

Consolaro, C., Rasmussen, T. L., Panieri, G., Mienert, J., Bünz, S., and Sztybor, K.: Carbon isotope $\left(\delta^{13} \mathrm{C}\right)$ excursions suggest times of major methane release during the last $14 \mathrm{kyr}$ in Fram Strait, the deep-water gateway to the Arctic, Clim. Past, 11, 669-685, https://doi.org/10.5194/cp-11-669-2015, 2015. 
Corrége, T.: The relationship between water masses and benthic ostracod assemblages in the western Coral Sea, Southwest Pacific, Palaeogeogr. Palaeocl., 105, 245-266, 1993.

Cronin, T. M.: Ostracods and sea level, in: Handbook of Sea-Level Research, First Edition, edited by: Shennan, I., Long, A. J., and Horton, B. P., John Wiley \& Sons, Ltd, Chichester, 249-257, 2015.

de Vos, A. P. C.: Three new commensal ostracods from Limnoria lignorum, Beaufortia, 4, 21-31, 1953.

de Vos, A. P. C. and Stock, J. H.: On commensal Ostracoda from the wood-infesting isopod Limnoria, Beaufortia, 5, 133-139, 1956.

Dickens, G. R.: Down the Rabbit Hole: toward appropriate discussion of methane release from gas hydrate systems during the Paleocene-Eocene thermal maximum and other past hyperthermal events, Clim. Past, 7, 831-846, https://doi.org/10.5194/cp7-831-2011, 2011.

Didié, C. and Bauch, H. A.: Species composition and glacialinterglacial variations in the ostracode fauna of the northeast Atlantic during the past 200,000 years, Mar. Micropaleontol., 40, 105-129, 2000.

Freiwald, A. and Mostafawi, N.: Ostracods in a cold-temperate coastal environment, western Troms, northern Norway: Sedimentary aspects and assemblages, Facies, 38, 255-274, 1998.

Frenzel, P. and Boomer, I.: The use of ostracods from marginal marine, brackish waters as bioindicators of modern and Quaternary environmental change, Palaeogeogr. Palaeocl., 225, 68-92, 2005.

Gemery, L., Cronin, T. M., Briggs Jr., W. M., Brouwers, E. M., Schornikov, E. I., Stepanova, A., Wood, A. M., and Yasuhara, M.: An Arctic and Subarctic ostracode database: biogeographic and paleoceanographic applications, Hydrobiologia, 786, 59-95, 2017.

Hopcroft, P. O., Valdes, P. J., O'Connor, F. M., Kaplan, J. O., and Beerling, D. J.: Understanding the glacial methane cycle, Nature Communications, 8, 14383, https://doi.org/10.1038/ncomms14383, 2017.

Horne, D. J., Cohen, A., and Martens, K.: Taxonomy, morphology and biology of Quaternary and living Ostracoda, in: The Ostracoda: Applications in Quaternary Research, edited by: Holmes, J. A. and Chivas, A. R., American Geophysical Union, Washington, DC, 5-36, 2002.

Iwatani, H., Irizuki, T., and Hayashi, H.: Global cooling in marine climates and local tectonic events in Southwest Japan at the PlioPleistocene boundary, Palaeogeogr. Palaeocl., 350, 1-18, 2012.

Joy, J. A. and Clark, D. L.: The distribution, ecology and systematics of the benthic Ostracoda of the central Arctic Ocean, Micropaleontology, 23, 129-154, 1977.

Karanovic, I. and Brandão, S. N.: Biogeography of deep-sea woodfall, cold seep and hydrothermal vent Ostracoda (Crustacea), with the description of a new family and a taxonomic key to living Cytheroidea, Deep-Sea Res. Pt. II, 111, 76-94, 2015.

Maddocks, R. F.: Three new species of podocopid Ostracoda from hydrothermal vent fields at $90^{\circ} 50^{\prime} \mathrm{N}$ on the East Pacific Rise, Micropaleontology, 51, 345-371, 2005.

Maddocks, R. F. and Steineck, P. L.: Ostracoda from experimental wood-island habitats in the deep sea, Micropaleontology, 33, 318-355, 1987.

Mesquita-Joanes, F., Smith, A. J., and Viehberg, F. A.: The ecology of Ostracoda across levels of biological organisation from individual to ecosystem: a review of recent developments and fu- ture potential, in: Ostracoda as Proxies for Quaternary Climate Change, edited by: Horne, D. J., Holmes, J., Rodriguez-Lazaro, J., and Viehberg, F. A., Elsevier, Amsterdam, 15-35, 2012.

Müller, G. W.: Die Ostracoden des Golfes von Neapel und der angrenzenden Meeres-Abschnitte, Fauna und Flora des Golfes von Neapel, 21, 1-404, 1894

Nisbet, E. G. and Chappellaz, J.: Shifting gear, quickly, Science, 324, 477-478, 2009.

Rodriguez-Lazaro, J. and Ruiz-Muñoz, F.: A general introduction to ostracods: morphology, distribution, fossil record and applications, in: Ostracoda as Proxies for Quaternary Climate Change, edited by: Horne, D. J., Holmes, J., Rodriguez-Lazaro, J., and Viehberg, F. A., Elsevier, Amsterdam, 1-14, 2012.

Sars, G. O.: Oversigt af Norges marine Ostracoder, Förhandlinger i Videnskabs-Selskabet i Christiania, 7, 1-130, 1866 (preprint, 1865).

Schellenberg, S. A.: Marine ostracods, in: Encyclopedia of Quaternary Science, edited by: Elias, S. A., Elsevier, Amsterdam, 2046-2062, 2007.

Sen Gupta, B. K., Platon, E., Bernhard, J. M., and Aharon, P.: Foraminiferal colonization of hydrocarbon-seep bacterial mats and underlying sediment, Gulf of Mexico slope, J. Foramin. Res., 27, 292-300, 1997.

Smith, C. R., Glover, A. G., Treude, T., Higgs, N. D., and Amon, D. J.: Whale-fall ecosystems: recent insights into ecology, paleoecology, and evolution, Annu. Rev. Mar. Sci., 7, 571-596, 2015.

Steineck, P. L., Maddocks, R. F., Turner, R. D., Coles, G., and Whatley, R.: Xylophile Ostracoda in the deep sea, in: Ostracoda and Global Events, edited by: Whatley, R. and Maybury, C., Chapman and Hall, London, 307-319, 1990.

Sztybor, K. and Rasmussen, T. L.: Diagenetic disturbances of marine sedimentary records from methane-influenced environments in the Fram Strait as indications of variation in seep intensity during the last 35000 years, Boreas, 46, 212-228, $2017 \mathrm{a}$.

Sztybor, K. and Rasmussen, T. L.: Late glacial and deglacial palaeoceanographic changes at Vestnesa Ridge, Fram Strait: Methane seep versus non-seep environments, Palaeogeogr. Palaeocl., 476, 77-89, 2017b.

Uchida, M., Ohkushi, K., Kimoto, K., Inagaki, F., Ishimura, T., Tsunogai, U., TuZino, T., and Shibata, Y.: Radiocarbonbased carbon source quantification of anomalous isotopic foraminifera in last glacial sediments in the western North Pacific, Geochem. Geophy. Geosy., 9, 1-26, https://doi.org/10.1029/2006GC001558, 2008.

Van Dover, C., Aharon, P., Bernhard, J., Caylor, E., Doerries, M., Flickinger, W., Gilhooly, W., Goffredi, S., Knick, K., and Macko, S.: Blake Ridge methane seeps: characterization of a soft-sediment, chemosynthetically based ecosystem, Deep-Sea Res. Pt. I, 50, 281-300, 2003.

Van Harten, D.: Deep sea hydrothermal vent eucytherurine Ostracoda: the enigma of the pore clusters and the paradox of the hinge, in: Ostracoda in the Earth and Life Sciences, edited by: McKenzie, K. G. and Jones, P. J., A.A. Balkema, Rotterdam, 571-580, 1993.

Whatley, R. C. and Coles, G. P.: The late Miocene to Quaternary Ostracoda of Leg 94, Deep Sea Drilling Project, Revista Española de Micropaleontología, 19, 33-97, 1987.

Whatley, R. C. and Eynon, M. P.: Four new Arctic deepwater ostracod species from East Greenland, in: Proceedings of the 2nd Eu- 
ropean Ostracodologists Meeting, edited by: Keen, M. C., British Micropaleontological Society, London, 195-200, 1996.

Whatley, R. C., Siveter, D. J., and Boomer, I. D.: Arthropoda (Crustacea: Ostracoda), in: The Fossil Record 2, edited by: Benton, M. J., Chapman \& Hall, London, 343-356, 1993.

Whatley, R. C., Eynon, M., and Moguilevsky, A.: Recent Ostracoda of the Scoresby Sund fjord system, East Greenland, Revista Española de Micropaleontología, 28, 5-23, 1996.

Whatley, R. C., Eynon, M., and Moguilevsky, A.: The depth distribution of Ostracoda from the Greenland Sea, J. Micropalaeontol., 17, 15-32, 1998.

Yasuhara, M. and Cronin, T. M.: Climatic influences on deep-sea ostracode (Crustacea) diversity for the last three million years, Ecology, 89, S52-S65, 2008.

Yasuhara, M. and Okahashi, H.: Quaternary deep-sea ostracode taxonomy of Ocean Drilling Program Site 980, eastern North Atlantic Ocean, J. Paleontol., 88, 770-785, 2014.

Yasuhara, M. and Okahashi, H.: Late Quaternary deep-sea ostracod taxonomy of the eastern North Atlantic Ocean, J. Micropalaeontol., 34, 21-49, 2015.

Yasuhara, M. and Seto, K.: Holocene relative sea-level change in Hiroshima Bay, Japan: a semi-quantitative reconstruction based on ostracodes, Paleontol. Res., 10, 99-116, 2006.
Yasuhara, M., Okahashi, H., and Cronin, T. M.: Taxonomy of Quaternary deep-sea ostracods from the western North Atlantic Ocean, Palaeontology, 52, 879-931, 2009.

Yasuhara, M., Grimm, M., Brandão, S. N., Jöst, A., Okahashi, H., Iwatani, H., Ostman, A., and Martínez Arbizu, P.: Deep-sea benthic ostracodes from multiple core and epibenthic sledge samples in Icelandic waters, Pol. Polar Res., 35, 341-360, 2014a.

Yasuhara, M., Stepanova, A., Okahashi, H., Cronin, T. M., and Brouwers, E. M.: Taxonomic revision of deep-sea Ostracoda from the Arctic Ocean, Micropaleontology, 60, 399-444, 2014b.

Yasuhara, M., Hunt, G., Okahashi, H., and Brandão, S. N.: Taxonomy of deep-sea trachyleberidid, thaerocytherid, and hemicytherid genera (Ostracoda), Smithsonian Contributions to $\mathrm{Pa}$ leobiology, 96, 216 pp., 2015.

Yasuhara, M., Tittensor, D. P., Hillebrand, H., and Worm, B.: Combining marine macroecology and palaeoecology in understanding biodiversity: microfossils as a model, Biol. Rev., 92, 199215, 2017. 